\title{
Evironmental Management at the Household, the case of Bekasi City
}

\author{
Ayu Arni Sarah ${ }^{1}$, Hayati Sari Hasibuan, ${ }^{2, *}$, and Donna Asteria ${ }^{3}$ \\ ${ }^{1}$ Magister Program of Environmental Science, School of Postgraduate Studies, Universitas Indonesia, Salemba- \\ Indonesia \\ ${ }^{2}$ School of Environmental Science, Universitas Indonesia, Salemba-Indonesia \\ 3Faculty of Social and Politics, Universitas Indonesia, Salemba-Indonesia
}

\begin{abstract}
The households have significant roles in managing the environment. The increasing of household numbers will automatically increase the demand and consumption of the resources, namely electricity, water, and land-use (space). The household also is a significant contributor to the solid waste in the city. The changing of lifestyle, consumption patterns and awareness of environment directly affects the environmental management at the household level. This paper examined the environmental management at the household level, in three aspects: (1) consumption of electricity and water, (2) green open space, and (3) waste management. This research using the quantitative method with data obtained from the survey on 30 respondents, all of the respondents are the household mother, with the assumption of they who manage the resources consumption and the environment in the household. This research found that the level of knowledge, attitude, and behavior in the waste management, water and electricity consumption and green open space management are good.
\end{abstract}

Keywords: Environmental management; household; waste management; water consumption, electricity consumption.

\section{Introductions}

Carbon reduction at the household level is an integral part of carbon mitigation and low carbon society [1]. The growth of human population from year to year tends to escalate the demands in the provision of various facilities of goods and services to support human needs, such as the need for clean drinking water, electricity, clean and healthy housing environment [2]. Stabilizing population growth and transiting resident's low carbon awareness to household behavior in energy saving and other spheres of consumption in the context of rapid growing population [1].

The principles of building low carbon society include: carbon minimization in all sectors, simpler life style that realize richer quality of life, and coexistence with nature [3]. The existing environmental, social, and and economic problem can be overcome by forming the character of low carbon society. The household is very strategic in the process of building low carbon society, in term of the energy consumption, daily commuting, garbage disposal, and water consumption [1].

Furthermore, human daily activities generate waste. Waste that is not properly managed, can decrease the aesthetics of the environment, cause unpleasant odors and as a place for the development of diseases that can interfere with human health $[4,5]$.

Population density causes environmental, social and economic problems. The existence of Green Open Space (RTH) affects the comfort of residents who are in a region. This indicates that everyday human activities contribute to changes in environmental order or environmental pollution which then degrade the quality of the environment to some degree until the environment cannot function properly $[6,7,8]$.

The rate of population growth in Kota Bekasi from 2010-2015 has increased by $14.6 \%$ per year [9]. The population of Bekasi City in 2010 amounted to $2,384,032$ people and increased to $2,733,240$ people by 2015. From these data, the population increase from 2010-2015 has increased by 349,208 people. The average garbage tonnage entering the TPA of Sumur Batu Kota Bekasi from 2011 to 2015 has increased by 503.53 ton/day [9]. The total mass waste in Bekasi City in 2011 weighed 395.01 ton/day to 898.54 ton/day in 2015.

In Jatiasih sub-district, especially Bumi Nasio area and IKIP complex, due to high rainfall and malfunctioning of waterways caused hundreds of houses to flood. The height of the flood reaches 140-170 centimeters [10].

* Corresponding author: hayati.hasibuan@ui.ac.id 
Furthermore, most households in Bekasi City buy clean water for drinking purpose. Approximately $41.31 \%$ of the population uses refill water while $29.53 \%$ of the population uses branded bottled water [11]. Conditions like this show that the city of Bekasi experiencing the clean water crisis and every year the condition is increasingly apprehensive.

The waste management system requires legal certainty, clarity of responsibilities and authority of the Regional Government, as well as the participation of communities and businesses so that waste management can proceed proportionally, effectively and efficiently [12]. One of the important dimensions that play a role in environmental issues is human behavior. In addition, Haruki Agustina, Head of Waste Sub-Directorate and Recycling at the Ministry of Environment and Forestry, said that women and families play a role in controlling the environment [13]. That is because 50 percent of the waste comes from households.

The three principles of Sustainable Development (SD), namely: social, economic, and environmental aspects, are implemented by involving all parties in the community. It indicates that community involvement is critical to realizing sustainable development, and women have great potential to act as agents of change in environmental preservation, environmental conservation and environmental pollution prevention $[14,15,16]$. The role of women in environmental management, especially waste management is related to the domestic function of women in the household, wherein carrying out the household activities the function of women is much in contact with household waste. In addition, the number of women is quite a lot. Women also proved able to overcome the surrounding environmental problems.

Women's empowerment program is aimed to improve the quality of life especially for women and their active participation in the community in prevention/control of pollution impact and environmental management that is good and true through social culture. Nowadays women's movements have emerged, to form forums or community groups that are distributors of community participation, especially women.

Communities have equal and equal rights and opportunities to take an active role in environmental protection and management [17]. With such participation, community members have a strong motivation to jointly solve environmental problems and seek the success of environmental management activities.

Based on the formulation of the problems that have been described then the purpose of research is to know the level of knowledge, attitude, and behavior of women (housewives) who have received education on the environmental management and environmentally friendly household.

\section{Pro-environmental Human Behavior}

Human behavior can be interpreted as a reflection of various psychological symptoms such as knowledge and attitude [3]. The relationship between man and the environment is circular. Changes in the environment will, in turn, affect humans. Currently, human behavior in relation with the surrounding environment experienced a major change. Human behavior is often less concerned with the surrounding environment by using as many natural resources as possible to meet the needs. Humans squander energy inefficiently, over-use of clean water, ignore reforestation and waste management that does not fit their individual characteristics that can cause problems for the environment. Effects arising from activities that reflect such inhospitable behavior lead to environmental degradation. Therefore, the interaction between man and his environment is important to maintain the sustainability of environmental functions.

\section{Waste Reduction and Management Behavior}

Waste issues arise because there is no balance between management capabilities and waste generated by individuals or households [3]. In developed countries, waste is not a problem in development because the institutional system is running well. There are mechanisms of fines, sanctions embedded through legal policies and regulations. From an early age, developed country people have been equipped with knowledge of environmental sustainability so that their awareness is good enough. This is reflected in the daily behavior is quite environmentally friendly.

Waste is the residue of a human daily activity, containing hazardous or toxic substances due to its nature, concentration, or quantity, either directly or indirectly, can harm the environment, health, humanity or other living beings [18]. Waste is grouped into three, ie waste based on its compounds, waste based on its form and waste based on its source [19].

The waste management law states that waste management should be conducted comprehensively and integrated from upstream to downstream so as to provide benefits to the environment, social and economic communities [20]. Waste reduction activities through reduce, reuse and recycle needs to be done at the housing level. This law sets out in detail how waste should be managed and how the duties and authorities of local, private and community governments manage waste. The law also regulates that managed waste consists of (a) household waste, (b) household garbage, (c) specific waste. Therefore, waste management must be in accordance with the characteristics of each so as not to disturb the balance of nature and cause problems for the environment.

The simplest waste management is to separate organic waste from inorganic waste. Waste processing into fertilizer is a simple effort that can be done by women to reduce the amount of waste that goes into landfill. In addition, waste processing into compost is beneficial to fertilize crops.

The roles and responsibilities of communities in waste management [12] include:

a. Prevention of the use of products and/or packaging that are not readily recycled and/or decomposed by nature; 
b. Implement and develop $3 \mathrm{R}$ principles in waste management at the source.

Consumers are an important source of preventive measures before consuming industrial products [21]. Environmental-friendly consumer preventive measures include making savings, reimbursements, rejection of non-environmentally-friendly products, repairing repairable products for extended life, reusing, not encouraging industries to produce something that is not part of basic needs, minimizing residual occurrences consume.

\section{Green Behavior}

Recalling the number of urban dwellers caused the condition of the environmental quality of urban settlements to decline $[22,23]$. This is due to the high demand for land for urban development that leads to the conversion of green land to wake land [24].

Greening is an attempt to balance the life of an area when the area has been transformed into a concrete jungle. The benefits of greening include aesthetic or beauty, hydrological, climatological, ecological, protective, hygienic [22].

In order to realize a comfortable space, safe and sustainable it is necessary spatial arrangement. At least $30 \%$ of the area must be RTH, with a composition of $20 \%$ public RTH and $10 \%$ private RTH [25]. While the city government of Bekasi states that the new city of Bekasi has $15 \%$ RTH. Of this $11 \%$ are private RTHs and $4 \%$ are public RTHs [26].

\section{Preserving Electric Energy Behavior}

Energy has a strategic role in human lives. The government must ensure the availability of sufficient quantities of electric energy, reasonable prices, and good quality. The increasing economy of a region, the need for electrical energy will also increase. Because of its role, it is feasible if energy saving behavior is used as an indicator to measure environmental caring behavior.

The use of installed electrical power can affect household behavior in everyday life. One effort to make the use of electrical energy does not exceed the existing load is to install energy-saving lamps in every room, do not turn on the light in the day, do not let the electronic equipment remains lit though not in use, wherever possible using household appliances used manually.

\section{Preserving Clean Water Behavior}

Human behavior in utilizing clean water sometimes is less wise [3]. Humans tend not to skimp when the amount of clean water is still abundant. Yet to keep in mind that the increasing population growth is proportional to the increase in the need for clean water. It takes time and complicated process to treat contaminated water into water that is suitable for drinking. If the amount of clean water has begun to be limited and difficult to obtain, people just realize the importance of clean water. One form of savings behavior in the use of clean water is to utilize the water formerly used to wash vegetable/fruits/meat/wudhu.

Furthermore, untreated household waste also causes environmental damage. The community tends to dispose of household wastewater into water bodies such as rivers, lakes and the sea. This household waste which causes clean water to be contaminated, so that contaminated water is no longer feasible for consumption by the community.

Conservating water, both groundwater and river water, lakes, and even sea water is a challenge regarding the environment. Clean water must be guarded against water pollution and excessive exploitation. Water pollution is caused by household activities and community activities that defecate in the open area.

\section{Methods}

\section{Research Approach}

This research uses descriptive quantitative research method approach. Quantitative methods are used to collect data on knowledge, attitude and behavior of women (housewives) in the effort to utilize electrical energy, manage waste, clean water utilization and greening efforts. Quantitative methods were conducted with surveys and data collection techniques with questionnaires. Interviews with women (housewives) using questionnaires were conducted by providing auxiliary card containing the answer option. The choice of answers given using the Likert scale method is correct and false for the knowledge questionnaire; strongly disagree, do not agree, agree and strongly agree to the attitude questionnaire; as well as never, ever, rarely, often and always for a behavioral questionnaire. The location of the research was conducted in Kota Bekasi. The study was conducted for three months, from December 2017 to March 2018.

\section{Population and Sample}

The population criteria in this research are:

a. Female (housewives) residing in Bekasi Town, South Bekasi Subdistrict, West Bekasi, East Bekasi, North Bekasi, Jatiasih, Jatisampurna, Medan Satria, and Mustika Jaya

b. Females (housewives) who follow environmental programs.

The determination of the number of samples from the existing population is based on random sampling. Sampling based on random sampling method was done by taking samples randomly because it is considered homogeneous so that it meets a minimum of 30 respondents. 


\section{Result and Discussion}

Table 1. Description of Woman Knowledge in Environmental Management

\begin{tabular}{|l|c|c|c|}
\hline \multicolumn{1}{|c|}{ Statement } & \multicolumn{2}{|c|}{ Knowledge } & $\begin{array}{c}\text { Total } \\
\%\end{array}$ \\
\cline { 2 - 4 } & False & True & \\
\hline Saving Electrical Energy Consumption & & 100.0 \\
\hline $\begin{array}{l}\text { 1. Turning off electronic } \\
\text { devices is an effort to save } \\
\text { electricity. }\end{array}$ & 0 & 100.0 & 100.0 \\
\hline Waste Reduction and Handling & 0 & 100.0 & 100.0 \\
\hline $\begin{array}{l}\text { 2. Using products with refill } \\
\text { systems, repairing damaged } \\
\text { goods and recycling used } \\
\text { good is an effort to prevent } \\
\text { the generated waste }\end{array}$ & 0 & 100.0 & 100.0 \\
\hline $\begin{array}{l}\text { 3. Food waste can be used as } \\
\text { fertilizer. }\end{array}$ & 0 & 100.0 & 100.0 \\
\hline $\begin{array}{l}\text { 4. Plastic bottles, cans, } \\
\text { styrofoam are a type of non } \\
\text { organic waste. }\end{array}$ & 0 & 100.0 & 100.0 \\
\hline $\begin{array}{l}\text { 5. Food waste is a type of } \\
\text { organic waste. }\end{array}$ & 0 & 100.0 & 100.0 \\
\hline $\begin{array}{l}\text { 6. The disposal of organic and } \\
\text { non-organic waste must be } \\
\text { seperated. }\end{array}$ & 0 & 100.0 & 100.0 \\
\hline $\begin{array}{l}\text { 7. Plastic waste that is burned } \\
\text { can pollute the environment. }\end{array}$ & 0 & 100.0 & 100.0 \\
\hline $\begin{array}{l}\text { 8. Household waste that is } \\
\text { disposed into drains can } \\
\text { contaminate water, clog the } \\
\text { pipe and cause flooding } \\
\text { during the rainy season. }\end{array}$ & 0 & 100.0 \\
\hline Save on Clean Water Consumption & \multicolumn{2}{|c|}{} \\
\hline $\begin{array}{l}\text { 9. Shower facility can save } \\
\text { water utilization. }\end{array}$ & 43.3 & 56.7 & 100.0 \\
\hline $\begin{array}{l}\text { 10. Household waste water } \\
\text { without chamical can be used } \\
\text { for plantation. }\end{array}$ & 0 & 100.0 \\
\hline $\begin{array}{l}\text { 11. Contaminated water can } \\
\text { not be used for drinking. }\end{array}$ & 0 & \multicolumn{2}{|c|}{} \\
\hline Greening & 0 & \\
\hline $\begin{array}{l}\text { 12. Planting and caring for } \\
\text { plants reduce urban heat } \\
\text { island and improve air } \\
\text { quality. }\end{array}$ & 0.0 & \\
\hline
\end{tabular}

Table 2. Description of woman attitude in environmental management

\begin{tabular}{|c|c|c|c|c|c|}
\hline \multirow{2}{*}{ Statement } & \multicolumn{4}{|c|}{ Attitude } & \multirow{2}{*}{$\begin{array}{c}\text { Total } \\
\%\end{array}$} \\
\hline & SD & D & $\mathbf{A}$ & SA & \\
\hline \multicolumn{6}{|c|}{ Saving Electrical Energy Consumption } \\
\hline $\begin{array}{l}\text { 1. Turn off unused } \\
\text { electronic devices. }\end{array}$ & 0 & 0 & 63.3 & 36.7 & 100 \\
\hline $\begin{array}{l}\text { 2. Turn off the lights } \\
\text { in the day. }\end{array}$ & 0 & 0 & 33.3 & 66.7 & 100 \\
\hline \multicolumn{6}{|c|}{ Save on Clean Water Consumption } \\
\hline $\begin{array}{l}\text { 3. Water flowing } \\
\text { without use makes } \\
\text { worried. }\end{array}$ & 0 & 0 & 56.7 & 43.3 & 100 \\
\hline 4. Reuse water. & 0 & 0 & 96.7 & 3.3 & 100 \\
\hline $\begin{array}{l}\text { 5. provide a water } \\
\text { catchment area. }\end{array}$ & 0 & 0 & 100 & 0 & 100 \\
\hline \multicolumn{6}{|c|}{ Waste Reduction and Handling } \\
\hline 6. Using refil system & 0 & 0 & 93.3 & 6.7 & 100 \\
\hline
\end{tabular}

\begin{tabular}{|l|c|c|c|c|c|}
\hline products. & & & & & \\
\hline $\begin{array}{l}\text { 7. Repair/ recycling } \\
\text { of damaged goods. }\end{array}$ & 0 & 0 & 100 & 0 & 100 \\
\hline $\begin{array}{l}\text { 8. Separating organic } \\
\text { and inorganic waste } \\
\text { before being } \\
\text { disposed. }\end{array}$ & 0 & 0 & 80.0 & 20.0 & 100 \\
\hline $\begin{array}{l}\text { 9. Does not burn } \\
\text { waste that has } \\
\text { accumulated. }\end{array}$ & 0 & 0 & 60.0 & 40.0 & 100 \\
\hline $\begin{array}{l}\text { 10. Do not bury } \\
\text { waste containing } \\
\text { chemicals. }\end{array}$ & 0 & 0 & 93.3 & 6.7 & 100 \\
\hline Greening & 0 & 0 & 86.7 & 13.3 & 100 \\
\hline $\begin{array}{l}\text { 11. Planting and } \\
\text { caring for plants. }\end{array}$ & \multicolumn{5}{|l|}{} \\
\hline
\end{tabular}

\section{Information:}

SD: Strongly Disagree

D: Disagree

A: Agree

SA: Strongly Agree

Table 3. Description of woman behavior in environmental management

\begin{tabular}{|l|c|c|c|c|c|}
\hline \multirow{2}{*}{ Pernyataan } & \multicolumn{5}{|c|}{ Behavior } \\
\cline { 2 - 6 } & N & E & R & O & A \\
\hline Saving Electrical Energy Consumption \\
\hline $\begin{array}{l}\text { 1. Turn off unused } \\
\text { electronic devices. }\end{array}$ & 0 & 0 & 6.7 & 13.3 & 80.0 \\
\hline $\begin{array}{l}\text { 2. Turn off the lights } \\
\text { during the day. }\end{array}$ & 0 & 0 & 0 & 3.3 & 96.7 \\
\hline Waste Reduction and Handling & 0 & 3.3 & 23.3 & 66.7 & 6.7 \\
\hline $\begin{array}{l}\text { 3. Using refill system } \\
\text { products. }\end{array}$ & 43.4 & 43.3 & 3.3 & 10.0 & 3.3 \\
\hline $\begin{array}{l}\text { 4. Repair damaged } \\
\text { items. }\end{array}$ & 0 & 6.7 & 60.0 & 30.0 & 33.3 \\
\hline $\begin{array}{l}\text { 5. Recycle used } \\
\text { goods. }\end{array}$ & 0 & 3.3 & 16.7 & 46.7 & 33.7 \\
\hline $\begin{array}{l}\text { 6. Processing organic } \\
\text { waste into fertilizer. }\end{array}$ & 0 & 0 & 0 & 20.0 & 80.0 \\
\hline $\begin{array}{l}\text { 7. Separating organic } \\
\text { and inorganic waste } \\
\text { before being } \\
\text { disposed. }\end{array}$ & 0 & 3.3 & 0 & 10.0 & 86.7 \\
\hline $\begin{array}{l}\text { 8. Does not burn } \\
\text { waste that has } \\
\text { accumulated. }\end{array}$ & 0 & 0 & 0 & 3.3 & 96.7 \\
\hline $\begin{array}{l}\text { 9. Does not throw } \\
\text { trash into water drain. }\end{array}$ & 0 & 0 & 0 & 0 & 100 \\
\hline $\begin{array}{l}\text { 10. Does not bury } \\
\text { waste containing } \\
\text { chemicals. }\end{array}$ & 0 & 0 & 3.3 & 0 & 96.7 \\
\hline Save on Clean Water Consumption \\
\hline $\begin{array}{l}\text { 11. Does not let water } \\
\text { flow without use. }\end{array}$ & 0 & 0.7 & 46.7 & 6.7 & 16.7 \\
\hline 12. Reuse water. & 16.7 & 20 & 46.7 & 33.3 \\
\hline Greening & 0 & 0 & \multicolumn{2}{|l|}{} \\
\hline 13. Caring for plants. & 0 & 0.3 & \\
\hline
\end{tabular}

\section{Conclusion}

Based on the results of the research, it is known that the behavior of women (housewives) in Bekasi City who follow environmental care program has been good in saving the consumption of electric energy, observing the 
consumption of clean water, waste management and afforestation. Household level environmental friendly behavior indicates the characteristics of low carbon society.

\section{Acknowledgment}

The author would like to give appreciation to the School of Environmental Science Indonesia University, and Hibah PITTA 2018 from Indonesia University for providing necessary support and fund for author's research and paper publication.

\section{References}

1. Xibao XU, Yan Tan, Shuang Chen, Gusihan Yang, \& Weizhong Su. Urban Household Carbon Emission and Contributing Factors in the Yangtze River Delta, China, PLoS One 10, 4 (2015).

2. Inoguchi, T., Newman, E., \& Paoletto, G. Kota dan Lingkungan, pendekatan baru masyarakat berwawasan ekologi. Terj. dari Cities and Environment : new approaces for eco-societies. (Suryandani, R. Penerjemah). Jakarta: LP3ES (2003).

3. Ministry of the Environment, Japan, Building a Low Carbon Society, December, 2007. https://www.env.go.jp/earth/info/pc071211/en.pdf

4. Dewi, Q.T. Penanganan dan pengolahan sampah. Jakarta: Penebar Swadaya (2008).

5. Sukandarrumidi. Rekayasa gambut, briket batubara dan sampah organik. Yogyakarta: Gajah Mada university Press (2009).

6. Ananta, C.Y., Sina La., \& Rika, E. Dampak kerusakan lingkungan akibat aktivitas pembangunan perumahan (sudi kasus di perumahan palaran city oleh PT. kusuma hady property). Jurnal Braja Niti 2, 11 (2013).

7. Sahubawa, Latif. Analisis dan prediksi beban pencemaran limbah cair pabrik pengalengan ikan. Jurnal Manusia dan Lingkungan, 18, 1 (2011).

8. Slamet, J.S. Kesehatan lingkungan, Hal 150-158. Yogyakarta: Gajah Mada University Press (2004).

9. Badan Pusat Statistik. Badan perencanaan pembangunan daerah kota Bekasi. Badan Statistik Kota Bekasi (2015).

10. Gobekasi. Banjir di komplek IKIP dan Bumi Nasio masih setinggi 1 meter lebih. http://gobekasi.pojoksatu.id/2017/04/12/banjir-dikomplek-ikip-dan-bumi-nasio-masih-setinggi-1meter-lebih/, 30 Desember 2017, pk. 13.04 WIB (2017).

11. Badan Pusat Statistik Kota Bekasi. Statistik daerah kota Bekasi 2014. Bekasi: CV Ratu Cemerlang (2014).

12. Peraturan Daerah Kota Bekasi Nomor 15 Tahun 2011 tentang Pengelolaan Sampah di Kota Bekasi. Lembaran Daerah Kota Bekasi Tahun 2011 Nomor 15 Seri E.

13. Dian, A. Hebatnya perempuan dalam pengelolaan lingkungan.

http://www.mongabay.co.id/2016/04/18/hebatnya- perempuan-dalam-pengelolaan-lingkungan/, November 2017, pk. 20.06 WIB (2016).

14. Koesrimardiyati, A. Keberlanjutan Pengelolaan Sampah Berbasis Masyarakat (Studi kasus peran perempuan dalam kegiatan pengelolaan sampah di RW 013 Cipinang Melayu Jakarta Timur). Tesis. Program Studi Ilmu Lingkungan Program Pascasarjana Universitas Indonesia, Jakarta (2011).

15. Puspitawati, H., Simanjuntak, M., Hayati, L. Kontribusi ekonomi dan peran ganda perempuan serta pengaruhnya terhadap kesejahteraan subjektif. Jurnal Ilmu Keluarga dan Konsumen, Vol. 5, No. 1 (2012).

16. Yayuk. Wanita dan lingkungan. Diunduh dari: http://blog.stie-mce.ac.id/yuyuk/2011/06/16/wanitadan-lingkungan/, 20 Desember 2016, pk. 10.24 WIB (2011).

17. Undang-undang Republik Indonesia Nomor 32 Tahun 2009 tentang Perlindungan dan Pengelolaan Lingkungan Hidup.

18. Notoatmodjo, S. Ilmu kesehatan masyarakat prinsipprinsip dasar, Hal 166-169. Jakarta: Rineka Cipta (2003).

19. Damayanti, S. Sampah adalah emas: hibah pengabdian kepada masyarakat. Jakarta: Universitas Indonesia (UI-Press, 2014).

20. Undang-undang Republik Indonesia Nomor 18 Tahun 2008 tentang Pengelolaan Sampah. Lembaran Negara Republik Indonesia Tahun 2008 Nomor 69.

21. Soerjani, M., Yuwono, A., \& Fardiaz, D. Lingkungan Hidup: Pendidikan, Pengelolaan Lingkungan dan Kelangsungan Pembangunan. Jakarta: Institute Pendidikan dan Pengembangan Lingkungan (2007).

22. Pramono, S.A. Penghijauan sebagai salah satu sarana mewujudkan kota berwawasan lingkungan. Jurnal Teodolita. Vol. 8, No. 2 (2007).

23. Wijayanto, W.T. Kajian ketersediaan ruang terbuka hijau di Kecamatan Gondokusuman Kota Yogyakarta tahun 2009. Jurnal Bumi Indonesia. Vol. 2, No. 3 (2013).

24. Ekaputra, Y.D., \& Sudarwani, M.M. Implikasi program pengembangan kota hijau (P2KH) terhadap pemenuhan luasan ruang terbuka hijau (RTH) perkotaan. Prosiding Seminar Nasional Sains dan Teknologi Fakultas Teknik Universitas Pandanaran. Vol.1, No. 1 (2013).

25. Undang-undang Republik Indonesia Nomor 26 Tahun 2007 tentang Penataan Ruang. Lembaran Negara Republik Indonesia Tahun 2007 Nomor 68.

26. Surjaya, Abdullah. Kota Bekasi baru memiliki 15\% Ruang Terbua Hijau. https://metro.sindonews.com/read/981842/171/kotabekasi-baru-miliki-15-ruang-terbuka-hijau1427400601, 3 Desember 2017, pk. 22.30 WIB (2015). 